\title{
A feasible method to extract DNA from the cambium of high-canopy trees: from harvest to assessment
}

\author{
Érica MANGARAVITE ${ }^{1,2}$, Vanessa TERRA³, Eric Koiti Okiyama HATTORI ${ }^{4}$, Thaís Carolina da Silva \\ DAL'SASSO $^{1}$, Leonardo Lopes BHERING ${ }^{5}$, Luiz Orlando de OLIVEIRA ${ }^{1, *}$

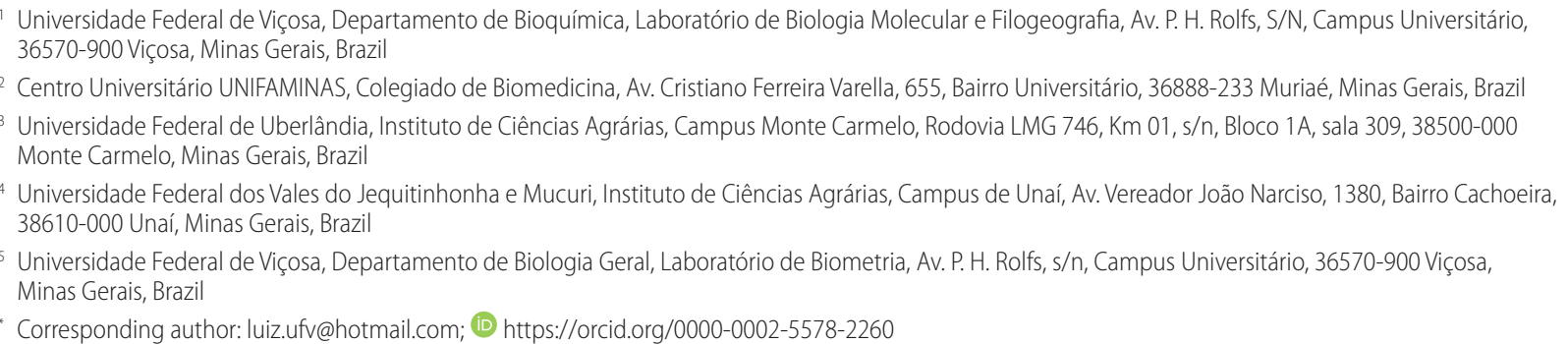

\section{ABSTRACT}

Many tropical trees have high canopies and their leaves are not accessible. Thus, the use of tissue from a more accessible organ (cambium) for DNA extraction may be an alternative for molecular studies. We adapted a feasible methodology for extracting genomic DNA from cambium tissue harvested in the field for the assessment with PCR. We tested three storage conditions (two buffers and a silica gel) and four periods of time after harvest. We used previously described protocols and tested them on three species that occur in Amazonian forests and other biomes: Anadenanthera peregrina var. peregrina, Cedrela fissilis, and Ceiba speciosa. Our protocol obtained suitable PCR-grade genomic DNA for DNA sequencing and microsatellite genotyping. We recommend the use of silica for long-term storage and the buffer with ascorbic acid for short-term storage.

KEYWORDS: ascorbic acid, dithiothreitol, DNA isolation

\section{Um método viável para extrair DNA do câmbio de árvores de dossel alto: da coleta à aplicação}

\section{RESUMO}

Muitas árvores tropicais possuem dossel alto e folhas não facilmente acessíveis. $\mathrm{O}$ uso de tecido de um órgão mais acessível (câmbio) para extraçáo de DNA pode ser uma alternativa para estudos moleculares. Nós adaptamos uma metodologia viável para extrair DNA genômico de tecido cambial coletado no campo para avaliaçáo com PCR. Testamos três condiçóes de armazenamento (dois tampóes e sílica gel) e quatro períodos após a coleta. Utilizamos protocolos descritos anteriormente e os testamos em três espécies encontradas em florestas amazônicas e outros biomas: Anadenanthera peregrina var. peregrina, Cedrela fissilis e Ceiba speciosa. Nosso protocolo foi eficaz na obtenção de DNA adequado para sequenciamento e genotipagem de microssatélites. Recomendamos o uso de sílica para armazenamento de longo prazo e o tampão com ácido ascórbico para curto prazo.

PALAVRAS-CHAVE: ácido ascórbico; ditiotrietol; isolamento de DNA

Molecular data has been helpful in revealing hidden aspects of the evolutionary history of plants (e.g., Hughes et al. 2013). The number of biodiversity studies using plant molecular data has increased over the last years (Vinson et al. 2018). Most of the traditional methods for DNA extraction from plants were designed to use leaves as the source of genomic DNA (e.g., Doyle 1990; Cota-Sánchez et al. 2006). However, many tropical trees have high canopies and their leaves are not readily accessible. Moreover, the vegetation of seasonally dry forests usually releases its leaves during the driest period (Oliveira-Filho and Fontes 2000). The use of commercial kits allows for the quick extraction of genomic DNA from leaves but adds cost to the analysis.

The use of an effective and inexpensive protocol that uses cambium tissue may be an alternative when leaves are not readily available. There are few studies that have used cambium 
tissue as a source of genomic DNA, but most of them adopted a time-consuming method using a commercial kit to achieve DNA extraction (e.g., Asif and Cannon 2005; Colpaert $e t$ al. 2005; Novaes et al. 2009; Lanes et al. 2013). Herein, we aimed to adapt a feasible methodology for extracting genomic DNA from cambium tissue, from the field sampling to the assessment of the DNA with PCR.

We sampled cambium tissue from three tree species that are native to the Amazon region and other Brazilian biomes: Anadenanthera peregrina (L.) Speg. var. peregrina (Fabaceae), Cedrela fissilis Vell. (Meliaceae) and Ceiba speciosa (A. St.Hil.) Ravenna (Malvaceae). Three trees of each species were sampled in Viçosa, Minas Gerais, Brazil (2045'S, 4252'W). To collect a piece of cambium, we used a puncher (diameter $=1 \mathrm{~cm}$; thickness $=0.2 \mathrm{~cm}$; length $=16 \mathrm{~cm}$ ) and hammered it into the tree trunk until it reached the wood fibrous layer. The extracted sample was cleaned with a piece of tissue paper and washed with $100 \%$ ethanol.

We collected three samples from each tree (nine samples per species). The first sample was kept in a dithiothreitol transport buffer ("DTT" treatment). The second sample was kept in an ascorbic acid transport buffer ("AA" treatment). Both samples were kept in 15-mL Falcon tubes wrapped in aluminum foil. The third sample was kept in an air-sealed plastic bag containing approximately $50 \mathrm{~g}$ of silica gel beads ("SIL" treatment). The DTT and AA buffers consisted of $2 / 3$ absolute ethanol and 1/3 1 $\times$ CTAB buffer (Colpaert et al. 2005). Instead of using DTT (or $\beta$-mercaptoethanol) and AA together in the transport buffer, as Colpaert et al. (2005) did, we tested them separately. For the DTT buffer, we added $3 \mathrm{mM}$ dithiothreitol; to the AA buffer, we added $0.3 \%$ (w $\mathrm{v}^{-1}$ ) ascorbic acid. We did not use $\beta$-mercaptoethanol in these buffers. The DTT and AA buffers were kept at $4{ }^{\circ} \mathrm{C}$ and the SIL was stored at room temperature (approximately $25^{\circ} \mathrm{C}$ ).

Another novelty of our study was to test whether the storage conditions decreased the overall quality of the genomic DNA over time. Extractions were performed after four storage periods: "D0" (extraction performed on the same day of harvest); and "D7", "D14", and "D21" (extraction performed 7,14 , and 21 days after harvest, respectively). Extraction from the SIL samples was performed only after 14 and 21 days to allow for tissue dehydration. Prior to DNA extraction, the buffer-stored samples (DTT and AA) were washed with distilled water, sliced, and dried with tissue paper. The SIL samples were only sliced. Approximately 40 to $70 \mathrm{mg}$ of each sample was placed into $2.0 \mathrm{~mL}$ microtubes together with two 3.2-mm chrome-steel beads per tube. The samples were then homogenized with a Bead Beater system (Mini-Beadbeater-24, BioSpec, Paulínia, SP, Brazil). We performed the genomic DNA extraction with three replicates following an eight-step protocol, based on Cota-Sánchez et al. (2006) (modified by
Riahi et al. 2010), which was here applied for the first time for cambium tissue. The eight steps were applied as follows:

1. We preheated the CTAB buffer (2\% CTAB, $100 \mathrm{mM}$ Tris-HCl, pH 7.5, 1.4 M NaCl, 20 mM EDTA, $\mathrm{pH}$ 8.0; $4 \%$ PVP; adding $1 \% \beta$-mercaptoethanol immediately prior to use) to $65^{\circ} \mathrm{C}$;

2. $800 \mu \mathrm{L}$ of the hot CTAB buffer were added to the $2.0 \mathrm{~mL}$ microtube with the samples and beads;

3. The samples were pulverized with a bead beater: $3 \mathrm{~min}$ at 2,500 oscillations per minute for the silica-dried samples, and $5 \mathrm{~min}$ at 3,000 oscillations per minute for the bufferstored samples. This step was repeated if the grinding was not complete after the first round;

4. The tubes were incubated at $65^{\circ} \mathrm{C}$ for 15 min with occasional swirling;

5. The samples were cooled on ice for $2 \mathrm{~min}$ and $750 \mu \mathrm{L}$ CIA solution (chloroform:isoamyl alcohol; 24:1) were added to each tube followed by invertion 50 times. The tubes were centrifuged for $15 \mathrm{~min}$ at 10,000 rpm (Eppendorf centrifuge 5424) and the supernatant was transfered to a new microtube and the CIA step was repeated;

6. The supernatant was transferred to a new microtube, 0.7-volume ice-cold isopropanol was added and followed by gentle invertion 10 times and centrifugation for $15 \mathrm{~min}$ at $10,000 \mathrm{rpm}$. The supernatant was discarded without disturbing the pellet;

7. The pellet was washed by adding $1 \mathrm{~mL} 70 \%$ ethanol. The microtube was centrifuged for $10 \mathrm{~min}$ at $10,000 \mathrm{rpm}$ and the ethanol was discarded. This step was repeated with $1 \mathrm{~mL}$ absolute ethanol. The pellets were then dried at room temperature, with care not to overdry them;

8. Each pellet was resuspended in $30 \mu \mathrm{L}$ TE buffer $(10 \mathrm{mM}$ Tris-HCl, $\mathrm{pH}$ 8.0, 0.1 mM EDTA, $\mathrm{pH}$ 8.0), containing RNAse A $\left(10 \mathrm{mg} \mathrm{mL}^{-1}\right)$. The DNA sample was incubated at $37^{\circ} \mathrm{C}$ for $30 \mathrm{~min}$ and then stored at $4{ }^{\circ} \mathrm{C}$.

DNA quantification and quality control were performed with a NanoDrop Spectrophotometer (Thermo Scientific). We next tested whether the genomic DNA was suitable for PCR. The genomic DNA was amplified (the internal transcribed spacer, ITS) with the primer pair ITS 4 (5'-TCCTCCGCTTATTGATATGC-3', White et al. 1990) and ITS Leu (5'-GTCCACTGAACCTTATCATTTAG-3', Baum et al. 1998). For the chloroplast gene, we amplified the intron of $\operatorname{trn} \mathrm{L}$ (UAA) (CD) with the primer pair C (5'-CGAAATCGGTAGACGCTACG-3') and D (5'-GTTTACTTTTGGGCATGCTTCG-3') (trnL intron region, Taberlet et al. 1991). The PCRs were performed with three replicates, and the amplification (ITS or CD) was considered positive when a single, sharp band of the size expected was visible on a $1 \%\left(\mathrm{w} \mathrm{v}^{-1}\right)$ agarose gel. We calculated the percentage of positive amplifications from each 
extraction period (D0, D7, D14, and D21) and each storage condition (DTT, AA, and SIL), for each species. We also used the microsatellite primers Acol15, Acol16 (Feres et al. 2012), Ced54, and Ced65 (Hernández et al. 2008) in order to test the suitability of the DNA. The PCR results were checked on $2 \%\left(\mathrm{wv}^{-1}\right)$ agarose gels. ANOVA and Tukey tests, implemented in RBio version 119 (Bhering 2017), were used to analyze the differences in the DNA concentrations and the percentages of positive PCRs among treatments within species.

The two storage conditions (DTT and AA) allowed for PCR amplifications that were not possible previously for frozen bark samples of $A$. peregrina (Novaes et al. 2009) (Table 1). The SIL storage at room temperature (approximately 25 ${ }^{\circ} \mathrm{C}$ instead of $4{ }^{\circ} \mathrm{C}$ for the buffer samples) exhibited some DNA degradation, which was likely due to the temperature difference. However, several positive PCR amplifications were obtained (Table 2). The SIL storage resulted in a higher amount of DNA compared to previous studies. For samples of A. peregrina var. peregrina stored in SIL, our methodology recovered genomic DNA (496 $\mathrm{ng} \mathrm{mL}^{-1}$ ) with a yield higher than previously reported (364 $\mathrm{ng} \mathrm{mL}^{-1}$, Novaes et al. 2009). During field expeditions, silica gel is more amenable to handling than liquid buffers. Additionally, the use of silica gel requires less storage space in the laboratory when considering the size of the plastic bags and the tubes in the refrigerator. Despite some DNA degradation, we recommend SIL for long-term storage.

DNA extraction after different storage periods of cambium tissue has not been previously reported. There was no significant difference in the genomic DNA yield or quality among the four storage periods and none significantly impaired the use of the samples for PCR. This suggests that cambium tissue can be harvested and kept for some weeks prior to DNA extraction, which is frequently convenient in fieldwork schedules. We showed that buffers with either DTT or AA were suitable for extracting the DNA right after sample harvest. Additionally, the AA buffer was easier to prepare and carry into the field, and then be added to the remaining buffer ingredients as needed. The SIL-stored tissues were difficult to process during the first weeks. Nonetheless, the cambium tissues preserved in SIL storage were amenable to PCR four weeks after harvest (data not shown).

Anadenanthera peregrina exhibited higher genomic DNA yield than C. speciosa (Table 1). The high standard deviations might be due to the different sizes of the source tissue samples. Genomic DNA storage in DTT or AA exhibited sharp bands of a high-molecular mass, with little to no smears, suggesting high integrity. The $\mathrm{A}_{260} / \mathrm{A}_{280}$ ratio values presented little variation among species. Most of the samples exhibited a $A_{260} / A_{280}$ ratio greater than 1.8 (Figure 1), suggesting high purity. As a consequence, amplifications via PCR were successful. All tree samples were amplified for the
Table 1. Concentrations of genomic DNA (ng $\left.\mu^{-1}\right)$ extracted from cambium samples of three tree species under different treatments (Treat) of storage time $(0,7,14,21$ days) and storage media (DTT = dithiothreitol transport buffer, AA = ascorbic acid transport buffer, SIL = silica gel beads) per species . Values are averages and standard deviations of three replicates.

\begin{tabular}{lccc}
\hline Treat & Anadenantheraperegrina & Cedrela fissilis & Ceibaspeciosa \\
\hline D0 & $328.1 \pm 202.9$ & $379.1 \pm 183.8$ & $155.8 \pm 76.7$ \\
D7 & $682.1 \pm 848.2$ & $353.8 \pm 367.3$ & $188.0 \pm 79.3$ \\
D14 & $395.8 \pm 276.8$ & $294.2 \pm 287.6$ & $187.0 \pm 180.3$ \\
D21 & $322.5 \pm 292.1$ & $213.0 \pm 189.5$ & $136.4 \pm 130.0$ \\
AA & $420.9 \pm 633.4$ & $269.9 \pm 184.8$ & $158.1 \pm 120.4$ \\
DTT & $374.8 \pm 226.0$ & $353.3 \pm 284.0$ & $182.1 \pm 133.6$ \\
SIL & $496.1 \pm 405.6$ & $247.3 \pm 352.9$ & $148.6 \pm 151.2$ \\
Average & 431.5 & 301.5 & 165.1 \\
\hline
\end{tabular}

Table 2. Percentage of positive amplifications per region (CD and ITS) of DNA extracted from cambium samples of three tree species under different treatments (Treat) of storage time $(0,7,14,21$ days) and storage media (DTT = dithiothreitol transport buffer, $\mathrm{AA}=$ ascorbic acid transport buffer, $\mathrm{SIL}=$ silica gel beads).

\begin{tabular}{|c|c|c|c|c|}
\hline & Treat & Anadenanthera peregrina & Cedrela fissilis & Ceibaspeciosa \\
\hline \multirow{7}{*}{$C D$} & DO & 100.0 & 94.4 & 55.6 \\
\hline & D7 & 88.9 & 83.3 & 61.1 \\
\hline & D14 & 96.3 & 100.0 & 85.2 \\
\hline & $\mathrm{D} 21$ & 100.0 & 92.6 & 100.0 \\
\hline & AA & 91.7 & 91.7 & 75.0 \\
\hline & DTT & 100.0 & 94.4 & 83.3 \\
\hline & $\mathrm{SIL}$ & 100.0 & 94.4 & 77.8 \\
\hline \multirow{7}{*}{ ITS } & D0 & 88.9 & 94.4 & 33.3 \\
\hline & D7 & 83.3 & 83.3 & 27.8 \\
\hline & D14 & 92.6 & 70.4 & 81.5 \\
\hline & D21 & 96.3 & 88.9 & 81.5 \\
\hline & AA & 83.3 & 86.1 & 61.1 \\
\hline & DTT & 97.2 & 86.1 & 55.6 \\
\hline & $\mathrm{SIL}$ & 94.4 & 72.2 & 72.2 \\
\hline \multicolumn{2}{|c|}{ Average } & 93.8 & 88.0 & 67.9 \\
\hline
\end{tabular}

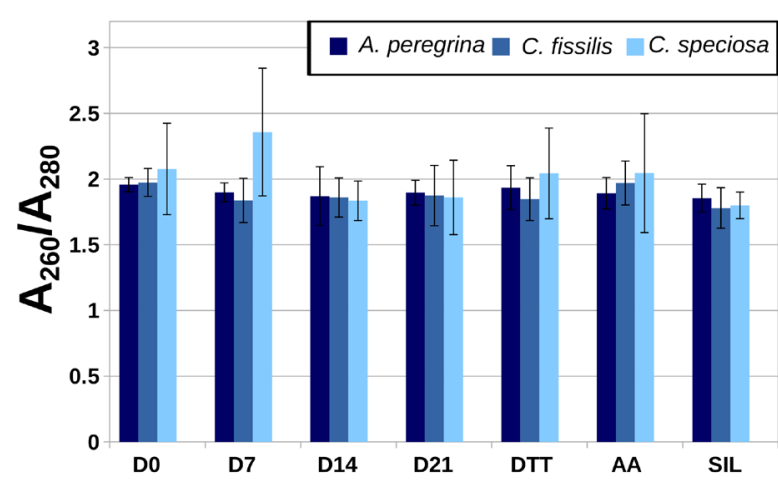

Figure 1. NanoDrop absorbances of the average $A_{260} / A_{280}$ ratios for DNA extracted from cambium samples of three tree species under different treatments of storage time $(0,7,14,21$ days) and storage media (DTT = dithiothreitol transport buffer, AA = ascorbic acid transport buffer, SIL = silica gel beads). The columns are averages of three replicates and the bar is the standard deviation. This figure is in color in the electronic version. 
tested regions. Anadenanthera peregrina exhibited the highest percentage of positive amplifications (Table 2) for the CD and ITS regions, followed by $C$. fissilis and C. speciosa. Sharp bands characterized most of the amplifications. We checked the PCR products for microsatellites and the presence of bands indicated its suitability for genotyping.

To our knowledge, this is the first report on a multiplexing PCR system with microsatellites applied to cambium tissue DNA, with potential for application in studies of the genetic diversity of tree species. We recommend the use of silica for long-term storage and the ascorbic acid transport buffer for short-term storage.

\section{ACKNOWLEDGMENTS}

EM is grateful to CAPES (Coordenação de Aperfeiçoamento de Pessoal de Nível Superior) for a fellowship from Oct/2012 to Feb/2014 and for an international fellowship from Apr/2015 to Mar/2016; and to CNPq (Conselho Nacional de Desenvolvimento Científico e Tecnológico) for a fellowship from Mar/2014 to Mar/2015 and from Apr/2016 to Jul/2016. LOO received a fellowship from CNPq (PQ304153/2012-5) and grants from FAPEMIG (Fundaçáo de Amparo à Pesquisa do Estado de Minas Gerais) (PPM-00561-15, 18 BPD-0028210) and CNPq (562249/2010-9).

\section{REFERENCES}

Asif, M.J.; Cannon, C.H. 2005. DNA extraction from processed wood: A case study for the identification of an endangered timber species (Gonystylus bancanus). Plant Molecular Biology Reporter, 23: 185-192.

Baum, D.A.; Small, R.L.; Wendel, J.F. 1998. Biogeography and floral evolution of Baobabs (Adansonia, Bombacaceae) as inferred from multiple data sets. Systematic Biology, 47: 181-207.

Bhering, L.L. 2017. Rbio: A tool for biometric and statistical analysis using the R platform. Crop Breeding Applied Biotechnology, 17: 187-190.

Colpaert, N.; Cavers, S.; Bandou, E. 2005. Sampling tissue for DNA analysis of trees: Trunk cambium as an alternative to canopy leaves. Silvae Genetica, 54: 265-269.

Cota-Sánchez, J.H.; Remarchuk, K.; Ubayasena, K. 2006. Readyto-Use DNA Extracted with a CTAB Method Adapted for Herbarium Specimens and Mucilaginous Plant Tissue. Plant Molecular Biology Reporter, 24: 161-167.
Doyle, J.J. 1990. Isolation of plant DNA from fresh tissue. Focus (Madison), 12:13-15.

Feres, J.M.; Monteiro, M.; Zucchi, M.I.; Pinheiro, J.B.; Mestriner, M.A.; Alzate-Marin, A.L. 2012. Development of microsatellite markers for Anadenanthera colubrina (Leguminosae), a neotropical tree species. American Journal of Botany, 99: e154-e156.

Hernández, G.; Buonamici, A.; Walker, K.; Vendramin, G.G.; Navarro, C.; Cavers, S. 2008. Isolation and characterization of microsatellite markers for Cedrela odorata L. (Meliaceae), a high value neotropical tree. Conservation Genetics, 9: 457-459.

Hughes, C.E.; Pennington, R.T.; Antonelli, A. 2013. Neotropical Plant Evolution: Assembling the Big Picture. Botanical Journal of the Linnean Society, X: 1-18.

Lanes, E.C.M.; Nick, C.; Kuki, K.N. 2013. Genomic DNA isolation of Acrocomia aculeata (Arecaceae) from leaf and stipe tissue samples for PCR analysis. Genetics and Molecular Research, 12: 3905-3911.

Novaes, R.M.L.; Rodrigues, J.G.; Lovato, M.B. 2009. An efficient protocol for tissue sampling and DNA isolation from the stem bark of Leguminosae trees. Genetics and Molecular Research, 8: 86-96.

Oliveira-Filho, A.; Fontes, M.A. 2000. Patterns of Floristic Differentiation among Atlantic Forests in Southeastern Brazil and the Influence of Climate. Biotropica, 32: 793-810.

Riahi, M.; Zarre, S.; Maassoumi, A.A. 2010. An inexpensive and rapid method for extracting papilionoid genomic DNA from herbarium specimens. Genetics and Molecular Research, 9: 1334-1342.

Taberlet, P.; Gielly, L.; Pautou, G.; Bouvet, J. 1991. Universal primers for amplification of three non-coding regions of chloroplast DNA. Plant Molecular Biology, 17: 1105-1109.

Vinson, C.C.; Mangaravite, E.; Sebbenn, A.M.; Lander, T.A. 2018. Using molecular markers to investigate genetic diversity, mating system and gene flow of Neotropical trees. Brazilian Journal of Botany, 41: 481-496.

White, T.J.; Bruns, T.; Lee, S.; Taylor, J.W. 1990. Amplification and direct sequencing of fungal ribosomal RNA genes for phylogenetics. In: Innis, M.A.; Gelfand, D.H.; Sninsky, J.J.; White, T.J. (Ed.). PCR Protocol: a Guide to Methods and Applications, Academic Press, Cambridge, p.315-322.

RECEIVED: $23 / 04 / 2020$

ACCEPTED: $19 / 08 / 2020$

ASSOCIATE EDITOR: Izeni P. Farias 